\title{
Development of Examination Behaviour Inventory: An Integrity Measure for Prevention of Cheating in School Exams
}

\author{
Moses C. Ossai ${ }^{1, *}$, Nathaniel Ethe ${ }^{1}$, Chukuka A. Okwuedei ${ }^{2}$ \& Dennis E. Edougha ${ }^{1}$ \\ ${ }^{1}$ Department of Educational Psychology, School of Education, Delta State College of Physical Education, Mosogar, \\ Nigeria \\ ${ }^{2}$ Department of Curriculum and Instruction, School of Education, Delta State College of Physical Education, \\ Mosogar, Nigeria \\ *Corresponding author: School of Education, Delta State College of Physical Education, Mosogar, PMB 4088, \\ Sapele, Nigeria. Tel: 234-806-426-4613. E-mail: ossaimoses@gmail.com
}

This research was funded by Tertiary Education Trust Fund (TETFund) of Nigeria through Delta State College of Physical Education, Mosogar, Nigeria.

Received: January 21, 2014

Accepted: February 25, 2014

Online Published: March 7, 2014

doi:10.5430/wje.v4n2p37

URL: http://dx.doi.org/10.5430/wje.v4n2p37

\begin{abstract}
Cheating in examinations is an educational menace that has threatened the very essence of schooling in most countries of the world. Therefore, it has become imperative for researchers in education to seek alternative strategies for curbing it in order to restore the dignity of school examinations as an instrument for assessing actual educational attainment by students. This research study addresses this challenge by developing an inventory that could be used to measure the examination behaviour of prospective candidates for school certificate examinations. The rationale for developing the instrument is based on providing a tool for identifying students who have positive tendencies towards engaging in cheating behaviour during school examinations. The initial sample used for the validation of the Examination Behaviour Inventory was 2000 candidates enrolled for the 2013 Senior School Certificate Examinations in Nigeria while the standardization of the instrument involved 4000 candidates. Cronbach Alpha index of the instrument is .843 and Factor Analysis delineated 12 principal component factors. Other psychometric properties of the inventory and the detailed processes involved in the construction, validation and standardization of this valuable educational instrument is reported. The instrument is recommended to School Counsellors, Psychologists, Teachers, Administrators and other stakeholders in education who are interested in the identification of prospective candidates who have a tendency to engage in cheating during examinations so as to apply proactive reformation on them.
\end{abstract}

Keywords: examination; behaviour; inventory; proactive strategies; malpractice; education; integrity

\section{Introduction}

In all countries of the world education has been considered to be the most veritable instrument for national development. It is also a tool for training the citizenry in order to live a better and rewarding life for themselves and for the society in general. In a nutshell, it has been described as the best legacy that any Nation or individual can leave behind for generations yet to come (Issa, 2011). Over the decades, education through the curriculum has been the means through which the school transmits the cultural heritage of societies. In all nations, the purposes of education are clearly stated in their philosophical postulations. These statements are concerned with what education will do for the improvement of the citizens of the society at large. They are aspects of the worthwhile cultural heritage that are supposed to be transmitted to children, youths and adults through the curriculum of schools. That is why Maduewesi, Aboho and Okwuedei (2010) stated that the curriculum is made up of all these essential and desirable aspects of the society's culture that the school should provide for the learners to enable them become educated to lead a better and rewarding life. By implication, the national philosophy of education encapsulates the educational objectives of the society, and they portray what the learners are supposed to learn as specific learning tasks. 
In Nigeria the formal, non-formal and informal systems of education has multilateral aims with the end objectives being to produce an individual who is honest, respectable, skilled, co-operative and conforms to the social order of the day. For example, Fafunwa's account (as cited in Maduewesi, Aboho \& Okwuedei, 2010) identified seven aspects of the informal education which are also applicable to the formal system of education, despite its multilateral nature, to include the development of the child's latent physical skills; character; respect for elders and those in position of authority; intellectual skills; vocational skills and healthy attitude towards honest labour; a sense of belonging and to participate actively in family and community affairs; and, appreciating and promotion of the cultural heritage of the community at large. If the above aims and objectives of informal and non-formal education are juxtaposed with those of the formal system of education in Nigeria as clearly enunciated in the National Policy on Education (Federal Republic of Nigeria, 2004) then the common goals of both systems of education are clearly delineated as the inculcation of national consciousness and national unity; the inculcation of the right type of values and attitude for the survival of the individual and the Nigerian Society; the training of the mind in the understanding of the world around; acquisition of appropriate skills; and the development of mental, physical and social abilities and competencies as equipment for the individual to live in and contribute to the development of the society.

In the light of all the above, Nigerian education was geared towards self-realization, better human relationship, self and national economic efficiency, good citizenship, national consciousness, national unity, social and political progress as well as national reconstruction. In pursuance of these objectives, therefore, our educational institutions from the pre-primary to university levels have designed their curricula programmes in such a way that functional individuals who will be capable of contributing their quota to national development are produced. It is, however, sad to say that these lofty goals of education are far from being realized in Nigeria due to the cankerworm called examination malpractice especially in the secondary schools (Obimba, 2002).

Examination is the process of finding out how much of the objectives of specific learning tasks a learner has assimilated (Bello, Kolajo \& Uduh, 2010). Fagbamuye's report (as cited by Bello et al) described examination as a tool for measuring and judging the standard of education in any country. They further asserted that examinations are used for selection, certification and reporting of progress to parents and policy makers. To them, results of public examinations are also used to monitor the performance of the educational system and as an accountability measure in schools. It is also regarded as a tool for measuring and judging the standard of education in any country. As an integral part of the curriculum process, it is thus an important tool in the teaching-learning process but the incidence of examination malpractices has made nonsense of examinations in the school system, especially in the secondary schools which is an important foundation of tertiary education.

In Nigerian secondary schools, examinations are internally and externally conducted. Internal examinations are school based while external examinations are referred to as public examinations. The internal examinations are developed and administered by schools using teacher-made tests whereas the public examinations are developed and administered by public examination bodies in Nigeria. These bodies include the West African Examinations Council (WAEC), the National Examination Council (NECO), the National Business and Technical Examinations Board (NABTEB), the National Teachers' Institute (NTI) and the Joint Admissions and Matriculation Board (JAMB). In all examinations, especially the public ones conducted by the bodies mentioned above, there are rules and regulations laid down to guide their conduct. Failure to adhere to these rules and regulations is called examination malpractice (Ossai, 2004; Cizek, 2001; Bello, Kolajo \& Uduh, 2010; Olanipekun, 2003). Examination malpractice has also been described as any act of dishonesty that occurs before, during and after an examination or assessment which is intended to obtain or offer an unfair advantage to a candidate or candidates in that examination or assessment (University of Exeter, 2002; Illoakasy, 1999; Afemikhe, 2010). Realizing the danger which examination malpractices pose to the educational system in Nigeria, the Federal Government enacted the Examination Malpractices Decree No. 33 of 1999 to curtail their occurrence. The act provides penalties ranging from imprisonment, fine or both for persons and bodies found guilty of involvement in, aiding, abetting, negligence or dereliction in the conduct of examinations. JAMB (2009) states that punishable offences under this Act include the following: cheating at examinations; stealing of question papers; impersonation; disorderliness at examinations; disturbances at examination; misconduct at examination; obstruction of supervisors; forgery of result slip; breach of duty; conspiracy and aiding. According to JAMB the courts will invoke appropriate penalties on persons and bodies found guilty of any of the offences under the Act. In this regard, coordinators, supervisors, invigilators and all individuals involved in examinations have been warned and advised to conduct themselves in a proper and responsible manner to avoid any breach of the law. In spite of these punitive measures put in place by the Examination Malpractice Act No. 33 of 1999 to ensure credibility in examinations, the conduct of examinations in Nigeria has continued to be bedeviled by examination malpractices which have been recognized to be the most intractable malaise that erodes the credibility of our examination system (Afemikhe, 2010; 
Ossai, 2010). Other offences that manifest themselves in form of examination malpractices according to Bello, Kolajo and Uduh (2010) include: leakage, collusion, bringing prepared answer scripts to the examination hall, swapping of candidates' scripts, sending answers to candidates using electronic gadgets, impersonation and unreliable continuous assessment scores from school authorities.

Paul and Bodunde's report (as cited in Esomonu, 2010), stated that the first episode of examination malpractice occurred in 1965 during the West African School Certificate Examinations; the very first time WAEC took complete charge of setting and conducting of the examination hitherto set in England by Cambridge Overseas Examination Board. According to Esomonu, this malpractice which probably began with leakage masterminded by some few dishonest workers has undergone some metamorphosis over the decades; growing in methods and techniques as well as number and caliber of practitioners. Most recently, some parents pay money to obtain question papers for their children and wards and sponsor these young ones to some examination centers known as "miracle centers". Some entice teachers to pass their dependents who have not done well enough in examinations. Some communities even go as far as launching examination comfort fund to enable their children excel in public examinations. In some cases, some teachers at secondary schools are involved by way of encouraging students to contribute money (cooperation fee) in order to secure the needed assistance during such examinations probably because they, the teachers, are aware of the inadequacy in the preparation of their students before examinations due to lack of adequate facilities and other factors (Odia \& Omofonwan, 2007).

\subsection{Rationale for the Inventory}

In recent times, examination malpractices have manifested in various forms, shapes and sizes with different designations such as 'microchips', 'macrochips', 'down-loads', 'laptops', 'giraffe' and quite recently the use of mercenaries. Microchips and macrochips have to do with small pieces and more significant sizes of papers, respectively, with prepared answers smuggled into the examination hall. 'Down-loads' simply refers to the act of bringing in of the whole textbook from which the candidate intends to copy. 'Laptops', which is most common with ladies, is the technique whereby the individual candidate's lap is used as the writing surface from where relevant information to an on-going examinations can be copied in the examination hall as the need arises. Giraffe is a style whereby candidates use neck stretching to look at what another candidate has written with the intent to copy. Another sophisticated method of examination malpractice is that of the examination mercenary syndrome. This refers to the practice whereby candidates employ and pay external persons to sit in and write examinations on their behalf.

Afemikhe (2010) cited the trend in examination malpractices in the June/July Senior School Certificate Examination (SSCE) conducted by the National Examination Council (NECO) in Nigeria for the period 2005-2009 in Table 1.

Table 1. Trend of Examination Malpractice in NECO June/July SSCE (2005-2009)

\begin{tabular}{lll}
\hline Year & Total Registered & Candidates Involved in Malpractice \\
\hline 2005 & 877,694 & $132,819(15.13 \%)$ \\
2006 & 939,019 & $112,695(12.00 \%)$ \\
2007 & $1,015,428$ & $127,028(12.51 \%)$ \\
2008 & $1,168,535$ & $88,884(7.61 \%)$ \\
2009 & $1,201,262$ & $149,102(12.58 \%)$ \\
\hline
\end{tabular}

Source: Okpala's account (as cited in Afemikhe, 2010).

As shown in Table 1, the number of candidates involved in examination malpractices is very alarming. Perhaps this led some writers like Bello, Kolajo and Uduh (2010) to conclude that examination malpractice has assumed new and wide dimension in WAEC SSCE like in other examinations in Nigeria. This unfortunate trend in examination malpractice has contributed in great measure to the diminishing standard of education in Nigeria. It has also helped to cast aspersion on candidates' certificates, which many often claim, have not always been a true reflection of the academic achievement of their holders in Nigeria. Due to this negative educational phenomenon, it is not surprising therefore, that many candidates who secured admission into higher institutions with such results have been much of a disappointment. They simply could not leave up to their billing in all ramifications.

There is no doubt, therefore, that examination malpractices in all ramifications are to be checkmated by stakeholders in the education sector. This is for the simple fact that to compromise academic standards is one sure way to mortgage the future of a people. A country's today, and whatever it stands for, represents the foundation of her tomorrow. Prevalence of examination malpractice indicates the weak foundation upon which the country's tomorrow is being built. 
This research represents an effort to proffer a preventive approach in the fight against examination malpractices. Since the punitive approach that has been in vogue for about a century in Nigeria has failed to curb the 'monstrous' examination malpractices, there is need, therefore, to look for alternative strategies in this war. Rather than wait for the candidates or students to engage in examination malpractices and thereafter they are punished for the wrongful act, it will be plausible to devise ways of preventing them from engaging in the act in the first instance. The aphorism, "prevention is better than cure" applies in this case. In other words, is it possible to develop an instrument that could be used to determine a student's likely behavioral disposition towards examination malpractices before he or she sits for examinations? This is the challenge of the present study.

The major purpose of the study is to construct, validate and standardize an Examination Behaviour Inventory (EBI) for Secondary School Students. In order to achieve this purpose, the study addressed the following specific objectives:

i. describe the processes involved in the construction, validation and standardization of an Examination Behaviour Inventory for secondary school students in Nigeria.

ii. state the psychometric properties of a validated and standardized Examination Behaviour Inventory;

iii. explain how a standardized Examination Behaviour Inventory could be used to measure students likely behavior in public examinations; and

iv. discuss the usefulness of the Examination Behavior Inventory.

The attainment of the above stated purpose and objectives of this study will give impetus to the war against examination malpractice in Nigerian schools especially the secondary schools and other countries of the world where the instrument will be adapted. Therefore, this study is very significant because it provided a new strategy for tackling the menace of examination malpractice. A proactive strategy was established by this study which is quite unique and different from the punitive measures adopted by school authorities, examination bodies and the government in the fight against examination malpractices. Thus, the students, teachers, counselors, parents, school administrators, examination bodies, the government and Nigerian society in general will benefit from the use of EBI.

\subsection{Theoretical Framework}

The construction and validation of an inventory to measure likely examination behaviour of students is based on the Theory of Planned Behaviour (TPB) as espoused by Ajzen (2006). Three basic considerations are involved in TPB, namely, attitude towards a particular behaviour (such as cheating in examinations); subjective evaluation of how significant others in the life of an individual view the behaviour (such as parents, teachers, friends, etc.); and perceived ease or difficulty of executing the behaviour or action (examination malpractices). These three considerations determine whether an "intention" to engage in the behaviour will be formed and ultimately lead to the exhibition of the "behaviour". These three basic components of TPB are referred to as "Attitude Toward the Behaviour" (ATB), "Subjective Norm" (SN) and "Perceived Behavioural Control" (PBC) respectively according to Ajzen. The phenomenon of examination malpractices is a behavioural variable which could be premeditated or spontaneously carried out when an opportunity presents itself. In either case, however, ATB, SN and PBC must be positively disposed towards the act. Hence, there are direct connections between ATB, SN, PBC and Behaviour (examination malpractices). In constructing the Examination Behaviour Inventory (EBI) these fundamental elements of TPB by Ajzen were considered. The primary elements of TBP described by Ajzen are Target, Action, Context and Time (TACT) in defining the behaviour of interest. The "Target" behaviour is cheating in examinations (Examination malpractices). The "Actions" are those observed and reported events in literature as constituting examination malpractices such as impersonation, copying from prepared material, spying, etc. The "Context" is the Senior School Certificate Examination (SSCE) in Nigeria. The "Time" entails prior to, during and after the actual examinations. Thus, examination behaviour covers actions taken before, during and after the writing of the examinations.

\section{Method}

\subsection{Construction of the Instrument}

Construction of a Test Blueprint to cover the components of examination behaviour as it relates to positive and negative actions before, during and after the public examination was carried out as presented in Table 2. Rules and regulations guiding the conduct of WAEC, NECO, NABTEB and JAMB examinations were consulted and adapted into the Test Blueprint along with other relevant materials on examination behaviour. A total of 50 items were initially constructed but these were prone down to 40 after initial item analysis from a pilot study and expert judgment of Senior Colleagues in educational measurement and evaluation. 
Table 2. EBI Test Blue Print

\begin{tabular}{lcccc}
\hline \multicolumn{1}{c}{ Construct Domains } & \multicolumn{4}{c}{ Phase Dimension } \\
\cline { 2 - 5 } & Pre-exam & During Exam & Post-exam Total \\
\hline 1. Preparation/Study Habits & 4 & - & - & 04 \\
2. Compliance With Exam Ethics/Rules and Regulations & 2 & 9 & 1 & 12 \\
3. Examination Anxiety & 2 & 3 & 1 & 06 \\
4. Collusion & 1 & 6 & - & 07 \\
5. Attitude towards Examination/Exam Malpractices & 5 & 1 & - & 06 \\
6. Post-Exam Behaviour & - & - & 5 & 05 \\
Total & 14 & 19 & 07 & 40 \\
\hline
\end{tabular}

As shown in Table 2, the forty items EBI were geared towards measuring the aspects of examination behaviour specified, namely, Study Habits (items 1, 2, 3, 8); Examination Anxiety (items 4, 5, 6, 23, 29, 34); Collusion in Examination Hall (items 13, 14, 16, 18,26, 27, 32); Examination Ethics (items 10, 11, 12, 15, 17, 19, 20, 21, 28, 30, 31, 33); Attitude towards Examination Malpractices (items 7, 9, 22, 24, 25, 40; and Post-Examination Behaviour (items 35, $36,37,38,39$ ). This procedure adopted in the construction of the EBI is similar to that used by Institute for Personality and Ability Testing (2003); Ezeh and Odo (1997); Bakare (1977); Buchanan, Goldberg and Johnson (1999); and Spielberger (1980) in the development of their respective instruments. The 40 items in EBI are: 1. Other activities interfere with my study schedule for examinations. 2. I find it difficult to remember answers to questions even if I have prepared well for examinations. 3. I become tired quickly when I am studying for examinations. 4. I worry a lot about forthcoming examinations. 5. I wish examinations did not bother me so much. 6 . During examinations, I find myself thinking about the consequences of failing. 7. Examination is not a true test of one's knowledge. 8 . The best way to pass examination is to prepare well for it. 9. All forms of examination should be eliminated from our educational system.10. Candidates should be allowed to register for SSCE in schools other than the one they attended.11. It is not bad to take advantage of leaked examination questions if one gets them by chance. 12. Examinations could go on smoothly without Supervisors/Invigilators. 13. I come early to the examination hall to enable me make arrangements with my friends on passing the examination. 14. Candidates should be allowed to cooperate among themselves to pass examinations.15. Uncooperative Supervisors/Invigilators should be dealt with by candidates after the examination.16. Sometimes I borrow materials such as biro, eraser, rulers, and calculator from other candidates in examination hall. 17. Candidates should be allowed to bring into the hall materials that can assist them to pass examinations. 18. Talking to other candidates in the examination hall should not be classified as examination malpractice.19. Sometimes I do not stop writing even when we are told to do so. 20. A candidate who does not wish to submit his answer booklet at the end of examination should be allowed to discard it. 21. Late candidates should still be allowed into the examination hall after 30 minutes of commencement. 22. Open book examination is the best form of examination. 23. I always feel very nervous during examinations that I forget what I studied. 24. Without examinations, there is no point going to school. 25. Examination malpractice is one of the worst crimes against humanity. 26. Sometimes I give and receive assistance from my colleagues in answering examination questions. 27. Sometimes I talk to other candidates inside the examination hall. 28. Sometimes I tear part of my question papers and answer sheet during the examination. 29. Even when I am well prepared for an examination, I still feel much tensed up during the examination. 30. Sometimes I delay before handing over the answer booklet to the invigilator at the end of the examination. 31. I am always tempted to read the questions when given the question paper even when we are told not to do so. 32. Before the examination begins, I think of getting help from supervisors/invigilators or other sources. 33. Bringing in prepared examination scripts is the best way to pass examination. 34. After examinations, I find it difficult to cope with awaiting result anxiety and have positive beliefs. 35. Influencing marks after examination is not examination malpractice. 36. After the examination, I prefer to use connections to pass my examination. 37. I ask my parents to pay for my results so that I pass my examination. 38. Candidates should be allowed to have access to examination officials after writing examinations. 39. I wish I had someone that would influence my examination results. 40. Examination malpractice is a risk like any other risk in life. 


\subsection{Research Design and Sample}

The descriptive survey design was used to generate two sets of data for analysis in order to validate and standardize the instrument. The first stage involved a sample size of 2000 out of a total number of 48704 candidates enrolled for the May/June 2013 WAEC SSCE in Delta State of Nigeria. Cronbach Alpha and Factor Analysis were run on the data generated using the Statistical Package for the Social Sciences (SPSS) version 17 to determine the reliability and validity of the EBI and the results are reported in the next section of this article. The second stage required a larger sample of 4000 candidates enrolled for the same certificate examination drawn from the six geo-political zones covering the entire country (Nigeria). The validated EBI was administered to the 4000 participants out of the 1689188 candidates that enrolled for the examination. Data collected from the second sample were analysed to establish the national norms of the EBI as reported in the results section. In the two stages, the Multistage Stratified Random Sampling technique was used to ensure representation of the various subsets of the population with regards to gender, age, type of school, Senatorial Districts, Local Government Areas, States and Geo-political zones of the country. This procedure was found very appropriate since it is consistent with the reported empirical descriptive survey model recommended in research literature for the study of human attributes as they occur in the real world (Akinboye \& Akinboye, 1998; Cherry, 2014).

\subsection{Administration and Scoring the EBI}

EBI is a paper and pencil test. Candidates taking the test are provided with the Test Inventory containing the instructions and the 40 items. The candidate is required to read the instructions and write his or her gender and age in the spaces provided and then proceeds to ticking the column that agrees with his or her behaviour or disposition towards examination situations from the following options: $\mathrm{SA}=$ Strongly Agree; $\mathrm{A}=$ Agree; $\mathrm{D}=$ Disagree; $\mathrm{SD}=$ Strongly Disagree.

When the EBI is administered to a single student, it may not be necessary for the student to write his or her name on the inventory. However, for group administration, it is recommended that numbers or codes be assigned to each student taking the test and this number or code should be pre-written by the administrator on the inventory which will be used later by the test administrator to identify each test taker. The idea is to prevent the psychological effect of biased response associated with students having to write their names on the inventory. During the process of developing the EBI it was not necessary to write names nor assign codes to the test takers since follow-up was not a consideration. Administration of the inventory takes about $20-30$ minutes. Generally, the test administrator ensures that the test taker is comfortable and assured that the results of the test will not result in any punitive action against the candidate. EBI is scored by assigning numerical values from $1-4$ to each response as contained below but items 8 and 25 are scored in reverse order because they are positively toned while all other items are scored as follows: $\mathrm{SA}=1 ; \mathrm{A}=2 ; \mathrm{D}=3$; and $\mathrm{SD}=4$. The numerical values scored on each item are added up to get a total score for each test taker. The minimum and maximum scores obtainable are 40 and 160 respectively. An individual's total score is interpreted by comparing it with the national norms presented in Table 6. The national mean score for male students is 104.43 while that of female students is 106.95 .

\section{Results}

\subsection{Reliability and Validation of EBI}

Cronbach Alpha index for the EBI is .843 which is above the .70 cut-off threshold for most Social Science research as stated by Institute for Digital Research and Education, UCLA (2013). Moreover, all 40 items contributed significantly to the overall Cronbach Alpha index (.843) as shown in Table 3. 
Table 3. Contribution of Each Item to the Overall Cronbach Alpha of .843

\begin{tabular}{|c|c|c|c|c|c|}
\hline Item & $\begin{array}{l}\text { Scale Mean if } \\
\text { Item Deleted }\end{array}$ & $\begin{array}{l}\text { Scale Variance if } \\
\text { Item Deleted }\end{array}$ & $\begin{array}{l}\text { Corrected Item- } \\
\text { Total Correlation }\end{array}$ & $\begin{array}{c}\text { Squared Multiple } \\
\text { Correlation }\end{array}$ & $\begin{array}{l}\text { Cronbach's Alpha } \\
\text { if Item Deleted }\end{array}$ \\
\hline $1^{*}$ & 103.6690 & 289.242 & .242 & .159 & .841 \\
\hline 2 & 103.2050 & 285.193 & .363 & .330 & .839 \\
\hline 3 & 103.3395 & 288.873 & .230 & .273 & .842 \\
\hline 4 & 103.3165 & 288.549 & .217 & .255 & .842 \\
\hline 5 & 103.3945 & 286.887 & .199 & .175 & .843 \\
\hline 6 & 103.0720 & 285.673 & .287 & .223 & .840 \\
\hline 7 & 103.0760 & 290.768 & .125 & .171 & .845 \\
\hline 8 & 102.4815 & 290.967 & .146 & .235 & .844 \\
\hline 9 & 102.7325 & 286.623 & .253 & .316 & .841 \\
\hline 10 & 103.4335 & 288.860 & .212 & .221 & .842 \\
\hline 11 & 103.0870 & 285.014 & .321 & .245 & .840 \\
\hline 12 & 102.8255 & 283.145 & .321 & .251 & .840 \\
\hline 13 & 103.3025 & 290.273 & .172 & .207 & .843 \\
\hline 14 & 103.5975 & 287.983 & .256 & .367 & .841 \\
\hline 15 & 102.7155 & 284.217 & .340 & .303 & .839 \\
\hline 16 & 103.2500 & 289.062 & .206 & .207 & .842 \\
\hline 17 & 102.9105 & 278.553 & .339 & .216 & .839 \\
\hline 18 & 103.5635 & 282.232 & .385 & .266 & .838 \\
\hline 19 & 103.2170 & 282.403 & .396 & .343 & .838 \\
\hline 20 & 103.0690 & 287.202 & .235 & .249 & .842 \\
\hline 21 & 103.5185 & 283.588 & .347 & .255 & .839 \\
\hline 22 & 102.5820 & 276.611 & .547 & .390 & .834 \\
\hline 23 & 103.2630 & 278.242 & .292 & .145 & .841 \\
\hline 24 & 103.8190 & 286.935 & .242 & .272 & .841 \\
\hline 25 & 102.9510 & 288.125 & .204 & .239 & .842 \\
\hline 26 & 103.6070 & 283.619 & .310 & .214 & .840 \\
\hline 27 & 103.5985 & 283.386 & .270 & .174 & .841 \\
\hline 28 & 102.5260 & 277.960 & .553 & .406 & .834 \\
\hline 29 & 103.2905 & 280.950 & .461 & .377 & .837 \\
\hline 30 & 103.1815 & 281.324 & .421 & .351 & .837 \\
\hline 31 & 103.3935 & 282.995 & .379 & .318 & .838 \\
\hline 32 & 102.6585 & 276.713 & .603 & .466 & .833 \\
\hline 33 & 102.6710 & 279.651 & .464 & .393 & .836 \\
\hline 34 & 103.4265 & 281.602 & .405 & .350 & .838 \\
\hline 35 & 102.9265 & 280.987 & .413 & .309 & .837 \\
\hline 36 & 102.4935 & 278.290 & .431 & .308 & .837 \\
\hline 37 & 102.4515 & 280.171 & .269 & .166 & .842 \\
\hline 38 & 102.7120 & 277.386 & .400 & .278 & .837 \\
\hline 39 & 102.7130 & 277.718 & .540 & .413 & .835 \\
\hline 40 & 103.9110 & 291.978 & .111 & .162 & .845 \\
\hline
\end{tabular}

*Item Serial Numbers.

Data in Table 3 shows internal consistency of all 40 items in EBI. According to Santos (1999) the value of an item to the overall Cronbach Alpha $(\alpha)$ is determined from the $(\alpha)$ index if the item is deleted. If the $\alpha$ improves significantly, it means that the item should be dropped but in this case deletion of any of the items will not lead to significant improvement in the overall $\alpha$ as seen in Table 3. Therefore, the EBI is internally consistent. Reliability over time was determined through test-retest over a period of four weeks on a sample of 60 SSCE candidates and Pearson correlation 
(r) for the two administrations is .85. This shows that EBI has high stability. Validity of the EBI was determined with Factor Analysis using Principal Component Analysis (PCA) of Statistical Package for Social Sciences (SPSS) version 17 as presented in Tables 4 and 5 .

Table 4. Principal Components Extracted from the 40 Item EBI

\begin{tabular}{|c|c|c|c|c|c|c|}
\hline \multirow[t]{2}{*}{ Component $^{*}$} & \multicolumn{3}{|c|}{ Initial Eigenvalues } & \multicolumn{3}{|c|}{ Extraction Sums of Squared Loadings } \\
\hline & Total & $\%$ of Variance & Cumulative \% & Total & $\%$ of Variance & Cumulative \% \\
\hline 1 & 6.456 & 16.141 & 16.141 & 6.456 & 16.141 & 16.141 \\
\hline 2 & 2.124 & 5.309 & 21.450 & 2.124 & 5.309 & 21.450 \\
\hline 3 & 2.023 & 5.058 & 26.508 & 2.023 & 5.058 & 26.508 \\
\hline 4 & 1.676 & 4.189 & 30.697 & 1.676 & 4.189 & 30.697 \\
\hline 5 & 1.507 & 3.767 & 34.464 & 1.507 & 3.767 & 34.464 \\
\hline 6 & 1.426 & 3.566 & 38.030 & 1.426 & 3.566 & 38.030 \\
\hline 7 & 1.322 & 3.304 & 41.334 & 1.322 & 3.304 & 41.334 \\
\hline 8 & 1.264 & 3.160 & 44.494 & 1.264 & 3.160 & 44.494 \\
\hline 9 & 1.239 & 3.097 & 47.591 & 1.239 & 3.097 & 47.591 \\
\hline 10 & 1.109 & 2.773 & 50.364 & 1.109 & 2.773 & 50.364 \\
\hline 11 & 1.044 & 2.610 & 52.973 & 1.044 & 2.610 & 52.973 \\
\hline 12 & 1.022 & 2.555 & 55.528 & 1.022 & 2.555 & 55.528 \\
\hline 13 & .948 & 2.370 & 57.898 & & & \\
\hline 14 & .919 & 2.298 & 60.196 & & & \\
\hline 15 & .912 & 2.280 & 62.476 & & & \\
\hline 16 & .899 & 2.248 & 64.723 & & & \\
\hline 17 & .824 & 2.061 & 66.784 & & & \\
\hline 18 & .794 & 1.984 & 68.768 & & & \\
\hline 19 & .770 & 1.925 & 70.694 & & & \\
\hline 20 & .761 & 1.902 & 72.596 & & & \\
\hline 21 & .730 & 1.825 & 74.420 & & & \\
\hline 22 & .711 & 1.778 & 76.198 & & & \\
\hline 23 & .693 & 1.734 & 77.932 & & & \\
\hline 24 & .683 & 1.709 & 79.641 & & & \\
\hline 25 & .663 & 1.659 & 81.299 & & & \\
\hline 26 & .647 & 1.618 & 82.917 & & & \\
\hline 27 & .615 & 1.537 & 84.454 & & & \\
\hline 28 & .604 & 1.511 & 85.965 & & & \\
\hline 29 & .570 & 1.426 & 87.391 & & & \\
\hline 30 & .553 & 1.382 & 88.773 & & & \\
\hline 31 & .536 & 1.341 & 90.114 & & & \\
\hline 32 & .520 & 1.300 & 91.414 & & & \\
\hline 33 & .503 & 1.257 & 92.671 & & & \\
\hline 34 & .459 & 1.148 & 93.819 & & & \\
\hline 35 & .454 & 1.135 & 94.955 & & & \\
\hline 36 & .444 & 1.110 & 96.065 & & & \\
\hline 37 & .418 & 1.045 & 97.110 & & & \\
\hline 38 & .403 & 1.007 & 98.117 & & & \\
\hline 39 & .394 & .985 & 99.102 & & & \\
\hline 40 & .359 & .898 & 100.000 & & & \\
\hline
\end{tabular}

*Extraction Method: Principal Component Analysis. 
Data in Table 4 show that 12 factors were extracted from the 40 item EBI. Those 12 factors accounted for 55.53\% variance among the independent variables (EBI items). Table 4 presents the factor loadings of the items on a threshold of .30. Factor loadings less than .30 were suppressed in the Factor Analysis since according to Precision Consulting (2013, p. 57) "a factor loading of less than .30 is not that significant". Most of the items loaded on Factor 1 which could best be described as "Examination Behaviour (During and Post-examination)". Other discernable factors are: Preparation/Study Habits (Pre-examination behaviours); Examination Anxiety; Examination Attitude; Assistance and Cooperation to cheat during Examination or Collusion. Items 32, 28, 22, and 39 had very high factor loadings on factor 1 at $.680, .639, .636$ and .627 respectively.

Table 5. Component Matrix of the 40 Items in EBI on the 12 Components Extracted

\begin{tabular}{|c|c|c|c|c|c|c|c|c|c|c|c|c|}
\hline \multirow{2}{*}{$\overline{\text { Item }}$} & \multirow[b]{2}{*}{1} & \multirow[b]{2}{*}{2} & \multicolumn{10}{|c|}{ Components* } \\
\hline & & & 3 & 4 & 5 & 6 & 7 & 8 & 9 & 10 & 11 & 12 \\
\hline 1 & & & & & & & & .393 & & & & .323 \\
\hline 2 & .379 & .371 & .305 & & & & & & & & & \\
\hline 3 & & .433 & & & & & -.355 & & & & & \\
\hline 4 & & .470 & & .352 & & & & & -.313 & & & \\
\hline 5 & & & & .304 & & & .318 & & & -.441 & & \\
\hline 6 & .326 & & & .404 & & & & & & & & \\
\hline 7 & & & & & & .326 & .482 & & & .301 & & \\
\hline 8 & & -.318 & .440 & & & .318 & & & & & & \\
\hline 9 & & & .543 & & & & & & & & & \\
\hline 10 & & .407 & & & & & & & .378 & & & \\
\hline 11 & .376 & & & & -.384 & & & & .315 & & & \\
\hline 12 & .377 & & .443 & & & & & & & & & \\
\hline 13 & & & .354 & -.446 & & & & & & & -.429 & \\
\hline 14 & & .484 & & -.535 & & & & & & & & \\
\hline 15 & .363 & & .464 & & & & & & & & & \\
\hline 16 & & & & & & .420 & & & & & & \\
\hline 17 & .385 & & & & & & .331 & & & & & \\
\hline 18 & .457 & & & & & & & & & & & .310 \\
\hline 19 & .480 & & & .301 & & & & & .338 & & & \\
\hline 20 & & & & & .595 & & & & & & & \\
\hline 21 & .407 & & & & & & & & -.383 & & & \\
\hline 22 & .636 & & & & & & & & & & & \\
\hline 23 & .341 & & & & & & & & & .327 & -.312 & \\
\hline 24 & .303 & & & -.337 & & .474 & & & & & & \\
\hline 25 & & -.342 & & & & & -.323 & .377 & & & & \\
\hline 26 & .357 & & & & & .372 & & & & & & \\
\hline 27 & .314 & & & & & & & & & .344 & .369 & \\
\hline 28 & .639 & & & & & & & & & & & \\
\hline 29 & .534 & & .357 & & & & & & & & & \\
\hline 30 & .512 & & & & & & & .427 & & & & \\
\hline 31 & .443 & & .321 & & & & & & & & & \\
\hline 32 & .680 & & & & & & & & & & & \\
\hline 33 & .561 & -.331 & & & & & & & & & & \\
\hline 34 & .494 & & & & &. .367 & & & & & & \\
\hline 35 & .504 & & & & & & & & & & & \\
\hline 36 & .525 & -.329 & & & & & & & & & & \\
\hline 37 & .338 & & & & & & & & & & & .355 \\
\hline 38 & .471 & & & & & & & & & & & \\
\hline 39 & .627 & & & & & & & & & & & \\
\hline 40 & & & & & .596 & & & & & & & \\
\hline
\end{tabular}

*Extraction Method: Principal Component Analysis. 


\subsection{Standardization of EBI}

Further to the reliability and validation of the EBI as described in the preceding section, national norms were established for the instrument. According to Pareek (2002, p. 37) "Norms are the standards against which a score can be judged as low, normal or high. Generally, these are calculated from data from a large sample $($ say 1,000$)$ in terms of the mean and standard deviation values". Moreover, norms are developed for particular groups such as gender, age, category of students and so on.

The procedure adopted in producing the national norms for the EBI involved selecting a large sample of 4000 students from the six geo-political zones of the country and the Federal Capital Territory of Abuja. Data collected from the 4000 participants were subjected to data analysis using SPSS version 17 software and the norms obtained are presented in Table 6.

Table 6. National Norms of the EBI

\begin{tabular}{cccccc}
\hline Gender & Mean Age & Mean EBI score & S. D. & Std. Error of Mean & Median Score \\
\hline Male & 17.00 & 104.43 & 23.03 & .59 & 105.00 \\
Female & 17.00 & 106.95 & 16.44 & .33 & 108.00
\end{tabular}

Data in Table 6 Show the national norms against which an individual's score on EBI should be judged. Scores below the mean are indicative of positive behavioural disposition towards engaging in examination malpractices while scores above the mean are pointers to negative tendency to engage in examination malpractices.

\section{Discussion}

EBI was developed for measuring the behavioural tendencies of prospective Senior School Certificate Examination (SSCE) candidates in examination conditions. Primarily it is to be used for determining whether a Senior Secondary School student has a positive or negative behavioural disposition towards engaging in examination malpractices as enunciated in the theoretical framework. The elements of the TPB regarding "TACT" were manifested in EBI. The "Target" behaviour was tendency to cheat in the 2013 SSCE. Responses to the EBI by the registered students for the examination and the data analysis demonstrated the reliability and validity of the EBI for identifying students who are favourably disposed towards cheating in examinations and therefore require reformative counselling to discourage them from actually engaging in examination malpractices. School Guidance Counsellors could use EBI scores as a basis for preventive counselling against examination malpractices. Studies have shown that Guidance and Counselling programmes in the school system is geared towards helping students improve in their study habits so as to be fully prepared for writing their examinations confidently without engaging in examination malpractices (Ossai, 2012, 2013; UNESCO, 2000a,b). Moreover, high examination anxiety has also been implicated by the Ossai (2013) study as one of the variables along with poor study habits that propels students to engage in examination malpractices. A good number of items in the EBI assess Study Habits and Examination Anxiety (see section on Construction of EBI for these items). Therefore, school Guidance Counsellors should help students who score low in these sections to improve their study habits as well as control their examination anxiety levels since poor study habits and high examination anxiety are always significantly correlated with positive tendency to engage in examination malpractices (Ossai, 2004, 2011, 2012, 2013). The implication of this correlation is that when Guidance Counsellors help students to improve their study habits and reduce their examination anxiety levels, they will be less prone to engage in the other acts of examination malpractices covered in the inventory such as collusion, violation of examination ethics, and so on. These various acts of examination malpractices covered by EBI were derived from literature on examination cheating behaviour and they constitute the "Action" component of TACT. The "Context" of the EBI was the May/June 2013 Senior School Certificate Examination in which 112865 candidates engaged in cheating behaviour out of 1671268 candidates who actually sat for the examination. This shows that the prospect for using EBI is enormous giving the prevalence of this educational menace in the country. Other stakeholders within the school system (students, teachers and administrators) will benefit by using the validated and standardized Examination Behaviour Inventory (EBI) to identify students who are likely to engage in examination malpractices. Such identified students will be subjected to relevant counselling therapies such as Cognitive Behavior Therapy (CBT) and Rational Emotive Behaviour Therapy (REBT) to reform or re-orientate them before they sit for the actual examinations. Moreover, students who are identified to be prone to examination malpractices based on their scores in the EBI will be assisted further through study habits induction and self-regulated learning strategies. Research has shown that Counselling therapies and study habits induction are very useful strategies for improving students' academic performance due to their efficacy in reducing debilitating 
examination anxiety which otherwise leads to involvement in examination malpractices (Ossai, 2013; Spielberger \& Vagg, 1987). The students who are thus helped will be saved from the ugly consequences of engaging in examination malpractices. EBI relates to "Time" in TACT by encapsulating the three dimensions of prior, during and after the actual examinations when the cheating behaviour occurs.

Consistent with the Subjective Norm component of the Theory of Planned Behaviour upon which EBI is based, a culture of intolerance of cheating behaviour in examinations must be established in all countries of the world. Teachers, School Administrators, Parents and Researchers in Education and Social Sciences will also find EBI very useful in their efforts to checkmate examination malpractices in all educational systems. The menace of examination malpractices pervades all educational system of the world even in developed countries. For instance, McCabe, Trevino and Butterfield (2001) concluded from a meta-analysis of a decade of research on cheating in academic institutions in America that "cheating is prevalent and that some forms of cheating have increased dramatically in the last 30 years" (p. 219). Denise Pope's account (as cited in Walker, 2012) further corroborates the McCabe et al (2001) report with the following words "between 80 and 95 percent of high school students admitted to cheating at least once in the past year and 75 percent admitted to cheating four or more times". Therefore, EBI is recommended for use by researchers in education and social sciences as a veritable tool for diagnosing students in high schools who may have the attitude and behavioural tendencies towards engaging in examination cheating behaviour. The instrument could be revalidated and used in other countries of the world. Teachers and School Administrators who are concerned about the dangers posed by the menace of examination malpractices to the very essence of schooling will also find this inventory useful in curbing the incidences of their occurrences in their schools. Every stakeholder in the education system of Nigeria and other countries of the world are appalled at the deplorable state of cheating behaviour in examinations. The EBI is simple enough to be administered by concerned teachers and school administrators who are genuinely interested in identifying students who may have tendencies towards cheating in examinations so as to provide reformative reorientation for them before they actually sit for certificate examinations. Parents and Guardians will also find the EBI useful for mapping the examination cheating profile of their children and wards. Well-meaning parents and guardians realize that cheating in examinations is the worst investment they can make for their off springs. Certificates acquired through examination malpractices are worthless as there will always be a day of reckoning in which holders of such certificates will have to demonstrate their knowledge and skills. Interested parents and guardians should use the EBI as an instrument to check their children's disposition towards engaging in examination malpractices with the objectives of dissuading those who will be identified by the EBI as examination malpractice prone from actually engaging in the act. If these important stakeholders in education (teachers, administrators, parents and researchers) take active interest and massively engage in the fight against examination malpractices by, for instance, utilizing the EBI measure appropriately, then the subjective norm would have been eliminated from the framework. The Perceived Behaviour Control component would have been strengthened as the students will realize that it may no longer be easy to engage in the cheating behaviour during examinations. Deployment of EBI in the school system requires collective action of all well-meaning stakeholders in education. Such collective action is necessary in order to tame this hydra-headed monster called examination malpractices.

The examination bodies (WAEC, NECO, NABTEB, NTI and JAMB) that have been in the frontline in the war against examination malpractices in Nigeria will also benefit from deployment of EBI in secondary schools. Even though these examination bodies have been in the forefront of the war against examination malpractices in the country, their efforts have produced limited results as the incidents of candidates engaging in examination malpractices have continued to rise over the years (Afemikhe, 2010). Therefore, EBI will be of interest to them since it will help to identify candidates who are likely to engage in examination malpractices rather than waiting for them to engage in the act before drastic measures are taken. EBI will help to restore dignity to the certificates of secondary school leavers. There is no doubt that the incidence of secret cult saga in Nigerian schools is linked with the menace of examination malpractices (Ossai \& Avwenagha, 2010). Students who cheat to obtain school certificates and pass the Unified Tertiary Matriculation Examination (UTME) often find out that they cannot cope with the academic rigours of higher education hence they seek succor in secret cults. Therefore, curtailing the menace of examination malpractices in Nigerian secondary schools through effective use of EBI will have far reaching positive consequences for the Nigerian educational system and the society in general. Those who engage in examination malpractices often find out to their chagrin that they have to defend their certificates someday and when they fail to justify the certificates they possess, they often resort to criminal activities. Hence, if this pandemic of examination malpractices is ripped in the bud, the Nigerian society will be better for it. 


\section{Conclusion}

Adequate care was taken in the construction, validation and standardization of the EBI to ensure that it serves the purpose of helping to diagnose students who have a tendency to engage in cheating behaviour during school examinations. This proactive strategy is worth trying in the face of the apparent failure of the punitive sanctions that have been used extensively over the years in most countries of the world. EBI as a tool for preventive action differs from the punitive strategy in that it aims at identification of students inclined to cheating for reformation before they sit for the examinations rather than wait for them to engage in the cheating and then they are punished. The instrument takes into practical cognizance all the elements of the Theory of Planned Behaviour (TPB) especially regarding attitude towards examination malpractices, the subjective norm or encouragement of the acts by people who should vehemently oppose them and the perceived ease of engaging in the actions. Examination Behaviour Inventory (EBI) is a valuable educational tool that should be used to measure the disposition of students towards examination malpractices. It has been proven to be a reliable and valid instrument for this purpose among secondary school students in Nigeria. Therefore, it is recommended for adaptation in other countries of the world as an instrument for diagnosing the tendency of students to engage in cheating behaviour in school examinations. Thereafter, school personnel such as counsellors, psychologists, teachers and administrators should devise proactive strategies to prevent such identified students from engaging in examination malpractices. It is hoped that such proactive strategies will contribute towards curbing the rising incidents of examination malpractices especially when used as complimentary to the existing punitive measures in most countries of the world.

\section{Acknowledgements}

This research was funded by Tertiary Education Trust Fund (TETFund) of Nigeria through Delta State College of Physical Education, Mosogar, Nigeria.

\section{References}

Afemikhe, O. A. (2010). Strategies for managing examination malpractice in public examinations. Journal of the Association for Educational Assessment in Africa, 5, 139 - 151.

Akinboye, J. O., \& Akinboye, D. O. (1998). Research methods. Ibadan: CYFO Behaviour Sciences Ltd.

Bakare, C. G. M. (1977). Study habits inventory. Ibadan: Psychoeducational Research Productions.

Ajzen, I. (2006). Constructing a TPB Questionnaire: Conceptual and methodical considerations. Retrieved from www.unibieleofed.delajzen\%construction\%20\%20questionnaire.pdfajzen2006

Bello, M. A., Kolajo, A. J., \& Uduh, C. A. O. (2010). Managing examination crisis in Nigeria: The West African Examinations Council's (WAEC's) experience. Journal of the Association for Educational Assessment in Africa, 4, 23-32.

Buchanan, T., Goldberg, L. R., \& Johnson, J. A. (1999). WWW Personality Assessment: Evaluation of an On-Line Five Factor Inventory. Paper presented at the Meeting of the society of Computers in Psychology, Los Angeles. Retrieved from http://Users.wmin.ac.UK/2buchant/downloads/scip99.Intml

Cherry, K. (2014). Introduction to research methods. Retrieved from http://psychology.about.com/od/researchmethods/ss/expdesintro.htm

Cizek, G. J. (2001). Cheating to the test. Carolina: Hoover Institution, Leland Stanford Junior University.

Esomonu, J. C. (2010). Examination malpractice: A threat to the realization of the Seven-Point Agenda. Nigerian Journal of Teacher Education and Teaching, 8(1), 360-366.

Ezeh, P. S. E., \& Odo, J. O. (1997). Students Adjustment Scale (SAS) Manual. Nsukka: Centre for Adjustment Studies Productions.

Federal Republic of Nigeria. (2004). National Policy on Education. Lagos: NERDC.

Illoakasy, C. E. (1999). The roles of teachers in combating unreliable examination in the Nigerian educational system. In S. I. Okoli \& L. U. Ezeani, (Eds.) Education in Nigeria: A critical analysis. Onitsha: Lincel Publishers.

Institute for Digital Research and Education, UCLA. (2013). What does Cronbach alpha mean? Retrieved from http://www.ats.ucla.edu/stat/SPSS/faq/alpha.html 
Institute for Personality and Ability Testing, Inc. (2003). Sixteen Personality Factor Questionnaire. Retrieved from www.cpsnova.edu/-cpphetp/16pf.html

Issa, A. O. (2011). The impact of cultism and examination malpractices on the quality of Education in the $21^{\text {st }}$ Century Nigeria. Retrieved from http://www.unilorin.edu.ng/publications/issa/Dr\%201ssa\%2012doc

JAMB (2009) Guidelines for supervisor and invigilators for the 2009 Universities Matriculation Examination (UME). JAMB: Abuja.

Maduewesi, B. U., Aboho, D. A., \& Okwuedei, C. A. (2010). A practical guide to curriculum development (3rd ed.). Onitsha: West and Solomon Corporate Ideals Ltd.

McCabe, D. M., Trevino, L. K., \& Butterfield, K. D. (2001). Cheating in academic institutions: A decade of research. Ethics \& Behaviour, 11, 219-232. http://dx.doi.org/10.1207/S15327019EB1103_2

Obimba, F. U. (2002). Periscoping examination malpractice in Nigeria from the viewpoint of secondary school students: A case for counselling. The Counsellor, 19, 202-211.

Odia, I. O., \& Omofonwan, S. J. (2007). Educational system in Nigeria: Problem and prospects. Journal of Social Sciences, 14, 81-86.

Olanipekun, N. O. (2003). Examination malpractice in Nigerian schools: An in-depth analysis. Offa: Royal Prestige Venture.

Ossai, M. C. (2004). Counselling for the preventing of examination malpractice: Study habit as a predictor of students' attitude toward examination malpractices. The Counsellor, 20, 1-12.

Ossai, M. C. (2010). The challenge of examination malpractices to quality educational assessment: Role of personality type and attitude as proactive strategies. Journal of Educational Assessment in Africa, 5, 265-274.

Ossai, M. C. (2011). Study habit predicts examination behaviour: An imperative for enhancing quality of college guidance and counselling. Mediterranean Journal of Social Sciences, 2, 23-28.

Ossai, M. C. (2012). Age and gender differences in study habits: A framework for proactive counselling against low academic achievement. Journal of Educational and Social Research, 2, 67-73.

Ossai, M. C. (2013). Study habits, anxiety and examination malpractice attitude. Saarbrucken, Germany: LAP LAMBERT Academic Publishing.

Ossai, M. C., \& Avwenagha, D. O. (2010). Causes, factors and effects of violence in Nigerian schools. Paper Presented at the 10th Annual Conference of the Nigerian Society for Educational Psychologist at Delta State University, Abraka.

Precision Consulting (2013). A guide to SPSS. New York: Precision Consulting Press.

Pareek, U. (2002). Training instruments in HRD and OD (2nd ed.). New Delhi: Tata McGraw Hill Publishing Company.

Santos, J. R. A. (1999). Cronbach's Alpha: A tool for assessing the reliability of scales. Journal of Extension, 37(2). Retrieved from www.joe.org/joe/1999apid/tt3.php

Spielberger, C. D. (1980). Preliminary professional manual for the test anxiety inventory. Palo alto, C. A.: Consulting Psychologists Press.

Spielberger, C. D., \& Vagg, P. R. (1987). The treatment of test anxiety : A transactional process model. In R. Shwarzer, H. M., Vander Ploeg \& C. D. Spielberger (Eds.), Advances in test anxiety research (Vol., 5). Lisse: Swets and Ziethinger.

UNESCO. (2000a). Module 1: Guidance. France: Ag 2i Communication.

UNESCO. (2000b). Module 2: Counselling. France: Ag 2i Communication.

University of Exeter. (2002). Procedures for handling cases of suspected cheating. Retrieved from http://www.el/afb/examinations/plagiarism.l

Walker, T. (2012). What can be done about student cheating? Neatoday-National Education Association. Retrieved from http://www/neatoday.org/2012/12/11/what-can-be-done-about-student-cheating/ 